Faruk Unkić ${ }^{1}$

\title{
REPRESENTATION AND DEVELOPMENT OF ELECTRONIC COMMERCE IN COMPANIES IN BOSNIA AND HERZEGOVINA
}

\section{SUMMARY}

Development of the world's information technology and their influence on all aspects of human life and work is largely reflected in the areas of Bosnia and Herzegovi$n a$. This is the time when most of the companies switch to the electronic way of doing business. Today, without Internet and electronic business, it is virtually unthinkable to realize the online business objectives and the more efficient to spend business processes.

We made research in the purpose of knowing how the electronic trade is represented in the business world in Bosnia and Herzegovina, if it is accepted by companies, institutions and others, if they are used and what they think about electronic trade.

The aim of the work is to explore the representation and development of electronic commerce in companies in Bosnia and Herzegovina, as well as to examine the prerequisites that must be fulfilled for the successful development of electronic commerce.

The research was based on conducting the survey with approx. 250 companies in Bosnia and Herzegovina. Interviewing was carried out electronically. The limitations of research consist in the fact that the research was carried out in a developing country where the use of information technologies is on a lower level than in developed countries.

Key words: Electronic commerce, companies, Bosnia and Herzegovina, development of electronic commerce.

JEL: $M 37$

1 Assistant professor, Faculty of Economics, University of Zenica, 72000, Zenica, Bosnia and Herzegovina.E-mail: funkic@infoteh.ba 


\section{INTRODUCTION}

The emergence of the internet meant the need to switch to the new business conditions, not only companies, but also the user in terms of obtaining the necessary information for the desired products and/or services. Given the enormous competitors companies must strive to satisfy as much as possible the needs of clients/buyers and try to keep them. Companies must build long-term relationships with customers, which are based on trust and Fidelity, which can greatly help them with information technologies in the form of a well-organized database, as one of the elements of electronic business.

In the conditions of constant struggle, and strong competition, companies find new strategies for achieving better market position and more successful business. One of the key strategies is the marketing orientation on clients from which the respective objectives are performed, applying elements of electronic business and modern e-marketing strategies. Marketing Strategy implies, constantly listening to the wishes of clients and their needs, establishing a constant communication and maintaining a relationship with clients. As a result of this strategy, clients will gain value through a series of product and service improvements. This trend is the result of continuous technological change, especially in the field of innovation in information-communication technologies, market development, improvement of production and service processes, changes in the process of production of physical goods in terms of Opening processes to customers. According to the latest research conducted in the world regarding the use of the Internet, a steady increase in Internet users has been observed. There is a similar situation in Bosnia and Herzegovina. In recent times, there have been strong advertising campaigns to promote (cheaper and faster) Internet access services as a medium. What we can conclude is that also Bosnia and Herzegovina is following world's trends in this area.

\section{Prerequisites for the development of electronic commerce in Bosnia and Herzegovina}

For the development of electronic commerce in Bosnia and Herzegovina, it is necessary to achieve the necessary institutional and technical requirements. The strategy for the future development of electronic commerce in Bosnia and Herzegovina is based on the following assumptions:

- Increasing the level of economic and overall social development (Economic assumptions);

- Increased connection between telecommunication and information systems (Technological assumptions); 
- Higher education of the population with regard to information technologies and knowing of the English language (Social assumptions)

- Adequate legal regulation of electronic commerce (Legal assumptions).

One of the problem that is evident in Bosnia and Herzegovina is insufficient legal regulations for this area of business, since the law on electronic operations has not yet been brought in (it has been in the draft for a long time). There is only the electronic signature Act, but it is not in possibility to implement, since there is no CER agency digital signatures.

Due to the importance of this work we have focused on the legal framework for the development of electronic commerce in Bosnia and Herzegovina, since without legal framework electronic commerce cannot live in its full splendor.

\section{Legal framework for the development of electronic commerce in Bosnia and Herzegovina}

The entity of Republic of Srpska has adopted the following legal regulations to create the conditions for electricity and electronic commerce ${ }^{2}$ :

- Law on electronic signature in Republic of Srpska

- Law on electronic Document in Republic of Srpska

- The law on Electronic operations in Republic of Srpska

- Regulations enabling the implementation of the Electronic Signature Act

The law on electronic signature in Republic of Srpska entity ${ }^{3}$ governs the right of physical and legal persons to use the electronic signature in administrative, judicial and other proceedings, business and other actions, and the rights, obligations and responsibilities of physical and legal persons in connection with giving of the electronic signature certificates in the RS. Electronic signature as a key element to business process management, should be completely replaced by a unique signature ${ }^{4}$. The most significant fields of application of the electronic signature are listed below:

- Electronic Business (e-business)

- Electronic commerce (e-Commerce)

2 http://www.aidrs.org/legislativa/zakonski_akti_koji_omogucuju_primjenu_e-servisa [Access: 03.01.2012]

3 The law was adopted by the National Assembly of Republic of Srpska 03.06.2008-"Republic of Srpska Official Journal”, No. 59/08

4 Day 30. November 2000, the European Commission adopted a new legal framework for the use and recognition of electronic signatures, according to: Carey, P. (2001). The Internet and E-Commerce: A hawksmere Report. London: Hawksmere, pp. 57. 
- Electronic Banking (e-banking)

- Electronic administration (e-Government)

- Electronic health (e-Healthcare)

- Electronic education (e-Learning)

It also adopted the rules which allow the implementation of the Electronic signature Act:

- Ordinance on measures to protect the electronic signature and the qualified electronic signature, the lowest amount of compulsory insurance and the application of organizational and technical measures to protect the certificate,

- Rulebook on technical rules for ensuring the correlation of the records of issued and revoked certificates of certification bodies in entity of the Republic of Srpska,

- Rulebook on the content and manner of keeping the Register of certification bodies for the issuance of qualified electronic certificates and

- Ordinance on records of certification bodies.

One of the essential laws for conducting electronic business is the law on electronic Document in entity Republic of Srpska ${ }^{5}$. This law governs the manner of using the electronic document in legal transactions, administrative, judicial and other proceedings, as well as the rights, obligations and liability of legal and physical persons, as well as other competent authorities and organisations exercising public authority in Electronic document. The use of an electronic document that is legally equitable and has the same legal validity as the classical document on paper seeks to enable the rapid and uninterrupted technological development of electronic business as well as progress in international position and action.

The law on Electronic operations in Republic of Srpska ${ }^{6}$ is the most important law that allows electronic business and it was adopted in 2009. All prerequisites for the development and implementation of the electronic business were full-filled. This law regulates the use of data, documents and messages in electronic form. Electronic operations essentially means the automation of business processes using information and communication technologies i.e. Carrying out all activities undertaken by legal and physical persons for the exchange of goods and services, using computers and modern communication technologies.

5 The law was adopted by the National Assembly of Republic of Srpska 17.09.2008-"Republic of Srpska Official Journal", No. 110/08

6 The law was adopted by the National Assembly of Republic of Srpska 09.06.2009-"Republic of Srpska Official Journal”, No. 59/09 
Adoption and implementation of these laws prevents the participation of the Republic of Srpska in the Information Society of Europe, i.e. improve business processes what will make Republic of Srpska entity competitive on the European market. It should be emphasized here that while the Electronic Trade Act of entity of the Republic of Srpska is covered by electronic commerce, it is necessary to adopt a special law on electronic commerce that would regulate this area, since in our neighbouring countries mainly The Electronic Commerce Act is independent from other legal determinancy.

In Federation of Bosnia and Herzegovina entity in regards to the creation of legal bases for the realization of electronic business, no law was adopted for the purpose of regulating this area of business. In order to harmonize legislation on electronic operations with EU and entity law, Federation of Bosnia and Herzegovina should also adopt following legal regulations:

- The Electronic Signature Act,

- The Electronic Document Act,

- The law on Electronic Business,

- The Electronic Commerce Act,

- Confidentiality Act,

- The Law on Information Security and

- Personal Data Protection Act.

The adoption of the law on electronic signature begins the process of creating the legal infrastructure which is necessary for the successful establishment, operation and development of the information society, creating the conditions for the application of electronic signature and exchange of electronic documents with the confidence of the widest public in the operation and use of the electronic signature, creating space for more intensive operation of the electronic commerce system. By adopting the law on electronic trade, it creates a legal framework for equating electronic forms of business with classical paper's form, which will create a significant competitive advantage for the economy and State administration authorities. This area has not been legally regulated in Bosnia and Herzegovina so far, which represents a significant obstacle to the development of the electronic trade, i.e. the economic development of Bosnia and Herzegovina ${ }^{7}$. So, in the Federation there is a legal void in the field of electronic business.

At the level of the State of Bosnia and Herzegovina there is only the law on Electronic signature (OJ Journal of Bosnia and Herzegovina, No. 91/06).

7 Domazet, A. and others (2010) Development of trade and domestic market in the Federation of Bosnia and Herzegovina, Sarajevo: Institute of Economics; Zagreb: Institute of Economics, pp. 165. 


\section{Research of the representation and development of electronic commerce in companies in Bosnia and Herzegovina}

\subsection{Purpose and objectives of the research}

Goal of the work is to explore the state and perspectives of the development of electronic commerce in Bosnia and Herzegovina, as well as to examine what are the prerequisites that must be fulfilled for the successful development of electronic commerce, also to answer the question of whether the current environment in Bosnia and Herzegovina is worth entering the area of electronic commerce and whether entry into this area represents a chance, also which strategies should be undertaken by joining this area of global business in order to survive and develop in such a dynamic market.

The main task of the research is to try to find answers to the following questions:

- In which development phase are the companies in Bosnia and Herzegovina when it comes to conducting electronic commerce?

- What are the key factors for the development of electronic commerce in Bosnia and Herzegovina?

- How do company managers in Bosnia and Herzegovina perceive and use information communication technologies and the Internet in electronic commerce?

- What is the way companies come to e-buyers and how they build a database of customers and potential buyers?

- How companies interact with customers from databases and which applications or intermediaries are used in the realization of electronic commerce?

- Do companies take care of legal regulations related to the field of electronic commerce and in general electronic business?

- How do companies manage to retain existing customers and how they manage to create strong and loyal connections with customers in comparison to traditional trade?

- Who and how does the company have the greatest impact on the development and implementation of electronic commerce?

- How is the efficiency of electronic commerce measured?

The results obtained by the research can be used to provide strategic recommendations for the development and implementation of electronic trade of companies in Bosnia and Herzegovina in order to increase their, both local and global competitiveness, as well as increasing competitive advantages. 


\subsection{Research hypothesis}

The paper examines the working general hypothesis.

The application of electronic commerce in companies in Bosnia and Herzegovina has a perspective of gradual growth, which is determined by legal, economic, technological and social factors.

From the working hypothesis the following helpful hypotheses are performed:

- Most of companies in Bosnia and Herzegovina show interest in the development of electronic commerce, although there is currently a small number of companies that use electronic commerce as a means of sales, distribution, marketing activities and other,

- Companies are planning to orientate on trade towards final buyers and state institutions, while a small number of companies have developed $B 2 B$ (business-to-business),

- Companies in Bosnia and Herzegovina recognize the importance of electronic commerce from the aspect of inclusion in global world and European trade flows and are aware of the internationalization of business by using electronic commerce,

- Companies do not have a strategy of electronic commerce on the Internet, nor the strategy of marketing activities through Internet, and what they intend to do in the future,

- Small and medium-sized companies can see the perspectives of trade Development on the global market using electronic commerce,

- The perspective of the development of electronic commerce lies in the young and educated users and managers of the companies, who have the aim to achieve the best effects, from the aspect of customer satisfaction, and from the aspect of sales and marketing communication.

\subsection{Research methods}

In line with the practice of scientific research work, a combination of several scientific methods and research methods of data collection was applied in this work. The combination of methods was necessary in order to achieve a higher level of cognition and higher level of precision, hence the relevance of the results obtained.

The data collection Instrument was a questionnaire. The method of data collection was a combination of electronic surveys and personal or correspondence communication. 
For the purpose of the investigation, interviews with the competent state, entity and cantonal ministries and institutions, chambers of commerce and international organizations, whose interest is the development of electronic commerce and electronic business were conducted.

\subsection{Limitations in the field of research}

The survey was based on conducting the survey with approx. 300 Companies in Bosnia and Herzegovina. Surveying was carried out electronically. The research limit is that only one number of e-mail users are provided with a survey, so that the results obtained by the survey do not have to show the real situation, as well as that the research is carried out in a developing country where the application of Information technology is far at a lower level compared to developed countries. On the other hand, the research includes only electronic commerce, as one of the elements of the electronic business, and the research has an influence and cultural aspect, as well as the uneven distribution of information-communication technologies on the entire Territory of Bosnia and Herzegovina. The research sought to obtain information from all over Bosnia and Herzegovina, but no feedback was provided from certain parts.

\section{Results of research and analysis}

In this section, findings of the research conducted are presented in order to confirm the hypothesis. The research focuses on examining the representation and development of electronic commerce in companies as well as the issues related to the development of electronic commerce or may possibly influence directly or indirectly on its development.

It is a pioneer survey, since there is insufficient knowledge of this area in Bosnia and Herzegovina.

In order to define the questionnaire, available literature and theoretical concepts, as well as applied research in the world, have been analysed. The questionnaire contained 43 questions, which could be answered with several possible answers and questions for the assessment of attitudes, which covered the following areas:

- Basic indicators of the existing level of information and communication infrastructure in companies,

- Application of electronic commerce in companies,

- Investments of companies in information-communication technologies and electronic commerce, 
- Barriers to the introduction of electronic commerce in companies,

- Benefits from the application of electronic trade in companies and

- Basic information about the companies.

The results were presented in a way to monitor the logic of the questionnaire and the research problem.

\subsection{Defining target group and sample selection}

The sample of the survey included 300 companies from Bosnia and Herzegovina, which fall into the ranking of small, medium and large companies by basic activity. Three relevant sources in $\mathrm{BH}$ were used to collect information about companies: Yellow Pages ${ }^{8}$, who works in $\mathrm{BiH}^{9}$ and business map of $\mathrm{BiH}^{10}$.

\subsection{Format survey}

The questionnaire was done using Google Docs and was generated to be displayed in the Web form. The companies were provided with an email with a follow-up letter in which the link to access the questionnaire was given, so clicking on the link came to the form for participation in the survey. Companies could easily answer all questions from the questionnaire. After responding to questions and confirming the completion of the survey process, the data was generated in a database that was later used in the analysis.

\subsection{Results of research and analysis}

\subsubsection{Pattern structure}

From the aspect of the company, the survey encompasses 300 companies from Bosnia and Herzegovina engaged in various activities as well as different sizes. The surveys were delivered to the companies by e-mail, after the previously realized contact that they would take part in the survey. Responses (response rate) of 128 companies were obtained, while 17 (percentage 5.67\%) companies didn't receive surveys, because of change or shutdown of e-mail address or from an incorrectly delivered

8 http://www.yellowpages-ba.com/glavna.htm

9 http://www.kostaradi.com

$10 \mathrm{http} / / / \mathrm{www} \cdot \mathrm{mapabih.com/index2.php?}$ 
email address. The receipt of the email received 283 companies or $94.33 \%$ of the ${ }^{11}$, which means they either opened the open installment ${ }^{12}$ ) or read (reader rate) contents of the e-mail. According to the book by Dave Chaffey's "Total Email marketing"13 and according to the book by Aaker, Kumar and Day "Marketing Research" rate rematch (response rate) to the CATI methodology ${ }^{14}$ that is $31 \%$, while the response rate by email ${ }^{15}$ is $20 \%$. According to research by Krile, $\mathrm{K}$, response rate for the area of Croatia is $14 \%{ }^{16}$, which corresponds to the Bosnian-Herzegovinian environment. Response rate in our case is $45.23 \%{ }^{17}$ which represents a satisfactory level in relation to the average of the so far conducted research by e-mail.

In the framework of samples covering 128 companies from the area of Bosnia and Herzegovina, there were $4.69 \%$ of state-owned companies, $4.69 \%$ were in mixed ownership and $90.63 \%$ were privately owned.

According to the company's ownership the pattern is quite homogeneous, i.e. participation in the survey is in the largest part of the company in private ownership.

From the aspect size of the company, participation in the survey took $83.6 \%$ of small companies, $11.7 \%$ of medium-sized and $4.7 \%$ of large companies. According to the size of the company, the sample is heterogeneous, with the largest proportion of small companies $(83.6 \%)$, followed by medium companies $(11.7 \%)$ and large companies $(4.7 \%)$.

The structure of the samples by type of company's activity is also heterogeneous. The most represented companies which in their activities are predominantly engaged in trade in wholesale and small make $32 \%$, followed by other social, social and personal service activities with $26.6 \%$.

Based on the number of replies by the company, it can be concluded that the largest participation in the survey was taken by companies from the urban parts of Saraje-

11 According to, Dave Chafefey: Total Email Marketing, Marketing Insight Ltd., Oxford, 2003, p. 7378 , Reader rate (open rate) is $60 \%$.

12 Baggott, C. (2007) Email Marketing by the Num8ers. Hoboken, New Jersey: John Wiley \& Sons, Inc., pp. 189.

13 Dave Chafefey: Total Email Marketing, Marketing Insight Ltd., Oxford, 2003, p. 73-78.

14 Computer Assisted Telephone Interviewing

15 Aaker, D. A., Kumar, V. and Day, G.S. (2001). Marketing Research. New York: John Wiley and Sons, taken from Chailom, P., \& Ussahawanitchakit, P. (2009). Strategic Focus through e-commerce-Based Operations and Performance of e-commerce Businesses in Thailand. European Journal of Management, 9(4), $1+$. Http://www.questia.com

16 Krile, K. (2004) Comparison of the application of the scoreboard of key social issues CATI and E-MAIL methodology, Zagreb: Faculty of Humanities and Sciences, University of Zagreb, Department of Psychology.

17 Respons rate $=$ Number of Answer/Reader rate (open rate) 
vo (32\%), Mostar (8.6\%), followed by Zenica (6.3\%), Banja Luka (4.7\%), Brčko (3.9\%) and Tuzla (3.1\%), while companies from rural parts participated less in the survey.

The sample for conducting the questionnaire consists of 150 companies from the entity Federation of $\mathrm{BiH}, 100$ companies from the entity of the Republic of Srpska and 50 companies from Brčko District. A larger part of the companies from the Federation of $\mathrm{BiH}$ entity participated in the survey.

Participation in the survey took $82 \%$ of companies from the Federation of BIH entities, $14.9 \%$ of companies from the entity of the Republic of Srpska and 4\% from Brčko District. Bearing in mind that the number of replies exceeds $14 \%$, which represents the percentage of the response ${ }^{18}$, sample companies from the Republic of Srpska entity can be taken as a reference.

\subsubsection{Basic indicators of the existing level of information communication infrastructure in companies}

A prerequisite for the successful development of electronic commerce is that companies possess the appropriate information-communication infrastructure within the company, in order to provide through their information system the possibility to exchange data with companies and/or for the purpose of performing a company on the electronic market.

To this end, the survey sought to identify the current level of development of information and communication infrastructure in the companies in Bosnia and Herzegovina, so that they could be adequately incorporated into electronic commerce.

One of the essential parameters is the number of computers in the company. Research has shown that the average number of computers per company is 42 computers, while one computer represents a minimal number of computers in the company, and 2300 the maximum number of computers in the company. But here we must separately observe the number of computers based on the size criteria of the company, since a small number of large companies possess a large number of computers, while a large number of small companies possess on average a smaller number of computers. So that the analysis of the data obtained can come to the realization that the average number of computers in small companies is 12 , in the middle 46 , in the big 576, and among large companies there is one company with 2300 computers $^{19}$.

18 Krile, K. (2004) Comparison of the application of the scoreboard of key social issues CATI and E-MAIL methodology, Zagreb: Faculty of Humanities and Sciences, University of Zagreb, Department of Psychology.

19 Because of the confidentiality of the data, we will not disclose the company. 
When we observe the number of computers in relation to the size of the company it can be concluded that companies regardless of the size of the company have the necessary number of computers to carry out one or more segments of electronic commerce.

Another, very important factor is the personnel structure of the company that is ready to use computers and is ready to accept the challenges of modern business, through the application of information-communication technologies. To this end, the companies were required to find out what percentage of employees use a personal computer in daily work in the company.

Based on the data obtained, it can be concluded that employees in their work mostly use computers, which is a very important parameter for the development of electronic commerce.

The necessary information infrastructure, in order for the company to be able to use electronic commerce, is to possess a local MrSteady Local Area Network).

From the standpoint of the local computer network, it can be concluded that most companies have the conditions for the realization of electronic commerce since $86 \%$ of companies have a local computer network, which is necessary for the realization of tasks that are required to be carried out within the company and the establishment of software solutions for the realization of the overall both software and hardware solutions of electronic commerce.

The analysis of the results showed that all companies that took part in the survey have an Internet connection, and without which in the modern mode of operation, electronic commerce could not be realised.

Most companies do not possess the Extranet, which is not an important element for the development of electronic commerce but is significant for those companies that are serious but they are engaged in electronic commerce.

Companies have different ways of accessing the Internet. A small number of companies have only one way of accessing the Internet. This constitutes a significant component for electronic commerce, given that more Internet access provides safer work and an alternative solution in case it reaches one communication channel to gaps or failure.

The graph shows that the largest approach of the company are achieved through ADSL connection, followed by wireless access (WiFi), access via cable internet, leased line and others. Companies usually combine Internet access through different connections, and the most common combination is via ADSL and wireless access (WiFi). 
Most companies own their own web site on the Internet. The table 23 gives an overview of the companies that own or do not own a website. Companies that do not have a Web site represent companies that do not yet have a vision of performing on the electronic market. They do not have the promotion of their own product on the Internet so that they represent companies that are still far from realizing any electronic trade vision.

Also, the result obtained in terms of using one of the aspects of electronic commerce does not indicate that companies in Bosnia and Herzegovina are on the way of introducing electronic commerce. More than $50 \%$ of companies have declared that they do not use any electronic commerce. Table 25 shows the structure of the answer.

The companies that gave a positive response to using some of the electronic commerce aspects were supposed to answer the question: "What time period was needed to introduce electronic commerce?" It was found that the time period of the realization of electronic commerce depends on the company itself and its willingness to e-business. The optimum time period for the realization of electronic commerce is up to one year.

The companies that gave a negative response were supposed to answer the question: "Does the company intend to introduce electronic commerce and when?"

Of the 67 companies that responded that they did not use any electronic commerce, $46.27 \%$ did not intend to import electronic commerce. The percentage of these companies compared to the total number of surveyed companies is $24.22 \%$, which is not a small number of companies.

More than $32 \%$ of companies did not realize a single order using electronic commerce. If there is an active participation in the electronic commerce of those companies that have realised their purchases in a percentage of more than $10 \%$, it can be concluded that only about $23 \%$ of companies use electronic commerce in the process of procurement, which is a small number compared to the previously presented Information, which speaks to the possibility of using informational communication technology in the procurement process.

From the aspect of income from electronic commerce, it is also the largest number of companies that do not use electronic commerce (44.53\%). And here we can take the criterion that the active participation in the electronic commerce of those companies that have realized in their sales a percentage is over $10 \%$. It can be concluded that in the process of selling only approx. $20 \%$ of companies use electronic commerce, which is a small number compared to the previously presented data, which speaks to the possibility of using information-communication technologies in the process of possibilities for the development of electronic commerce. 
In support of this statement, $63 \%$ of companies stated that electronic commerce represents a long-term strategy of the company.

When asked whether companies intend to extend the use of electronic commerce in the next 12 months, a little less than half of the companies responded to the plan, while $50.78 \%$ of the companies did not plan to extend the electronic commerce.

This means that a large number of companies still do not understand neither the significance of the electronic business, nor the electronic commerce as the most important segment of electronic business. A large number of companies will continue to use the classic ways of doing business and will be required to make additional efforts in the management training to change this situation, if not for the implementation of electronic commerce in our own company, then for inclusion in electronic commerce as buyers of goods and services.

\subsubsection{Application of electronic Commerce}

The largest number of companies use the Internet for the purpose of research of competition, then to research and evaluate new suppliers. Small number of companies have turned to consumer analysis but still a percentage of $55.47 \%$ says that companies are still trying to exploit the Internet infrastructure in creating relationships with consumers as well as exploring the views of consumers regarding their products and services.

Each medium has its own specific determinants to which companies must count, so that their message is decoded by the recipient. The Internet as a newer medium, the use of which requires additional skills, has users of certain demographic, educational and cultural characteristics, so this is an additional request to the companies when generating the message.

In the survey conducted, the largest number of companies use the Internet as a medium to display information about the company and the offer of products and services (88.28\%), while (83.59\%) companies have a web page set up on their own server or on the server of another companies. Companies to a lesser extent, use advertising on the website of another company $(50.78 \%)$ or to promote their own electronic catalogue $(50.78 \%)$.

Companies need to understand the reasons for advertising over the Internet in view of the increasing number of Internet users, an increasing number of Internet sites, an increasing number of users of the Internet which shows that the Internet has become a respectable medium and that it cannot be ignored in the advertising industry. 
Also, the Internet allows targeted advertising, which with less spent resources, achieves better customer reactions. Advertising over the internet is on average cheaper than other media, especially television, and it should be taken into account, that due to cost price, messages can be clearer and less time-consuming.

On the user side, care should be taken of the comfort of shopping and simple ordering. Users who buy for the first time can be suspicious of online purchases, so it is certainly necessary to create quality support pages, where the ways and times of delivering, instructions for use and navigation will be described, as well as answers to the most common problems and Questions, because the visitors of electronic commerce in most cases are not professionals who are familiar with the technologies behind electronic commerce. Since Internet trading does not imply physical contact, quality customer support will be one of the main reasons why the buyer will decide to purchase in a specific company. Sometimes the impression that a customer gains by using electronic commerce is more important than the price they will pay for some goods.

The companies in Bosnia and Herzegovina devote the most attention to personal communication with customers via electronic mail, so that $89.84 \%$ of companies apply this customer support system. A large number of companies receive and process customer requests via online communications (73.44\%), as well as provide feedback using online communication channels. A good indicator is that companies take care to update products and services on their website (70.31\%), then to have on their site frequently asked questions and answers as a knowledge base that increases over time, so that the user can directly look for answer to some questions that are unclear to him and which are given in the earlier answers. Companies have neglected the need to register users on their pages $(46.09 \%)$, and this is a very important element in creating a database of visitors and allowing the same to be forwarded to the company's e-mails and advertising content.

Companies within the Web site can create an order form, which can be easily linked to the database of products in stock, thereby integrating the internal information system and business processes within the company with the environment via electronic commerce. Also, in addition to these possibilities, users are provided with detailed instructions for ordering and delivering procedures.

Companies in Bosnia and Herzegovina do not have a very enviable level from the aspect of enabling online receipt and processing of customer orders (54.69\%). Only one part of the company (53.91\%) performs online reconciliation of orders with suppliers.

Less than half of the companies (44.53\%) carry out the monitoring and delivery of goods using the opportunities provided in electronic operations. 
Payments are an integral part of business operations, regardless of whether it is traditional or Electronic Business. Electronic payments include the transfer of money and the execution of payments using electronic technology. Electronic payments of high value are carried out using private information networks. The users of these networks are banks and other financial institutions. Such networks are also used to carry out international payments, and for internal payment transactions. Small-value payments are electronically carried out using payment cards, or previously mentioned payment systems.

The companies in Bosnia and Herzegovina use the most online payments using the electronic banking provided by commercial banks (67.97\%). Although commercial banks allow companies to use both credit and debit cards for payment purposes, a very small number of companies use these payment instruments. Companies that have declared that they use other payment methods probably do not use the payment methods.

Credit cards are used by $36.72 \%$ of companies, while debit $31.25 \%$. Having in mind the simplicity of payment, the possibility of deferred payment and other benefits through these cards this percentage is very small.

\subsubsection{Barriers to the introduction of electronic trade in companies}

In order to explore possible barriers to the introduction of electronic commerce in the company's business, the arithmetic mean and standard deviation of the response for each potential obstacle is calculated. Every potential obstacle was assessed at five degrees of the Likert scale: Very low, low, moderate, high and very high. The results are given in table 1 .

As we see in table 1 respondents for the greatest obstacle to the introduction of electronic commerce, they consider a small social awareness of the buyers about electronic commerce $(\mathrm{M}=3.53 ; \mathrm{SD}=1.28)$. All other potential barriers to the introduction of electronic commerce in the company are considered moderate, except that they disagree with the assertions that the information obtained by the Internet is not useful $(\mathrm{M}=2.02 ; \mathrm{SD}=1.03)$, as electronic commerce is not as effective as traditional forms of marketing $(\mathrm{M}=2.37$; $\mathrm{SD}=1.11)$, as electronic commerce leads to disruption of existing distribution channels $(\mathrm{M}=2.33 ; \mathrm{SD}=1.11)$ and how the learning costs of electronic trade are high $(\mathrm{M}=2.46$; $\mathrm{SD}=1.08)$.

Table 2 below provides the results of checking the normality of the distribution of the responsiveness of respondents to questions about barriers to the introduction of electronic commerce in companies. Indicators that were used are kurtosis and skewness. 
Table 1: Arithmetic mean and standard deviation of respondents response to questions about barriers to the introduction of electronic commerce in the company.

\begin{tabular}{|c|c|c|c|}
\hline & $\begin{array}{l}\text { Number of } \\
\text { respondents }\end{array}$ & $\begin{array}{l}\text { Arithmetic } \\
\text { mean }\end{array}$ & $\begin{array}{l}\text { Standard } \\
\text { deviation }\end{array}$ \\
\hline The costs of introducing electric shops are high & 128 & 2.71 & 1.07 \\
\hline Insufficient financial resources & 128 & 2.69 & 1.09 \\
\hline Lack of time to introduce El. Store & 128 & 2.70 & 1.11 \\
\hline $\begin{array}{l}\text { It is necessary to employ additional workers to deploy and } \\
\text { maintain the electric store }\end{array}$ & 128 & 2.74 & 1.25 \\
\hline $\begin{array}{l}\text { Non-compliance of investment costs with } \\
\text { desired positive results }\end{array}$ & 128 & 2.83 & 1.18 \\
\hline Information obtained by electric trade is not useful & 128 & 2.02 & 1.03 \\
\hline The market potential of El. Store users is small & 128 & 2.84 & 1.23 \\
\hline $\begin{array}{l}\text { Our Sales/marketing requires a high degree } \\
\text { of personal communication }\end{array}$ & 128 & 3.20 & 1.29 \\
\hline El. Trade is not as effective as traditional forms of marketing & 128 & 2.37 & 1.11 \\
\hline Most vendors do not have access to the El. Store & 128 & 2.80 & 1.29 \\
\hline El. Trade leads to disruption of existing dis. Channels & 128 & 2.33 & 1.11 \\
\hline Insufficient security of online transactions & 128 & 2.57 & 1.29 \\
\hline Insufficient protection against viruses and hackers & 128 & 2.73 & 1.26 \\
\hline Insufficient eligibility of application manufacturers & 128 & 2.59 & 1.06 \\
\hline $\begin{array}{l}\text { Insufficient qualification of staff for the introduction and main- } \\
\text { tenance of the El. Store system }\end{array}$ & 128 & 2.67 & 1.12 \\
\hline $\begin{array}{l}\text { Lack of knowledge about potential forms } \\
\text { of application of El. Trade }\end{array}$ & 128 & 2.70 & 1.10 \\
\hline $\begin{array}{l}\text { Lack of government standards and legislation on electronic } \\
\text { commerce issues }\end{array}$ & 128 & 3.45 & 1.25 \\
\hline Telecommunication infrastructure is not an adequate & 128 & 2.67 & 1.21 \\
\hline $\begin{array}{l}\text { Lack of national strategy for the development } \\
\text { of electronic commerce }\end{array}$ & 128 & 3.45 & 1.31 \\
\hline $\begin{array}{l}\text { Lack of adequate strategy for the development of electronic } \\
\text { commerce and weak support } \\
\text { of the company's top management }\end{array}$ & 128 & 2.80 & 1.22 \\
\hline Lag in the application of new technologies & 128 & 2.91 & 1.21 \\
\hline $\begin{array}{l}\text { The customer's social awareness of electronic commerce is } \\
\text { very small }\end{array}$ & 128 & 3.53 & 1.28 \\
\hline $\begin{array}{l}\text { Cultural and linguistic barriers restrict the use of electronic } \\
\text { commerce }\end{array}$ & 128 & 2.46 & 1.24 \\
\hline Legal regulations & 128 & 3.11 & 1.25 \\
\hline Lack of security & 128 & 2.91 & 1.24 \\
\hline High learning costs & 128 & 2.46 & 1.08 \\
\hline Lack of knowledge & 128 & 2.67 & 1.18 \\
\hline $\begin{array}{l}\text { A small number of companies that developed this aspect } \\
\text { of trade }\end{array}$ & 128 & 3.13 & 1.13 \\
\hline The nature of the products which produces my company & 128 & 2.91 & 1.37 \\
\hline
\end{tabular}


Table 2: Verification of the normality of distribution of responsiveness by respondents to questions about barriers to the introduction of electronic commerce in the company.

\begin{tabular}{|c|c|c|c|}
\hline & $\begin{array}{l}\text { Number of } \\
\text { respondents }\end{array}$ & Kurtosis & Skewness \\
\hline The costs of introducing electric shops are high & 128 & -0.14 & 0.17 \\
\hline Insufficient financial resources & 128 & -0.28 & 0.17 \\
\hline Lack of time to introduce El. Store & 128 & -0.61 & 0.05 \\
\hline $\begin{array}{l}\text { It is necessary to employ additional workers to deploy and } \\
\text { maintain the electric store }\end{array}$ & 128 & -0.89 & 0.16 \\
\hline $\begin{array}{l}\text { Non-compliance of investment costs with desired positive } \\
\text { results }\end{array}$ & 128 & -0.94 & -0.09 \\
\hline Information obtained by electric trade is not useful & 128 & -0.08 & 0.72 \\
\hline The market potential of El. Store users is small & 128 & -0.69 & 0.12 \\
\hline $\begin{array}{l}\text { Our Sales/marketing requires a high degree of personal commu- } \\
\text { nication }\end{array}$ & 128 & -0.86 & -0.24 \\
\hline El. Trade is not as effective as traditional forms of marketing & 128 & -0.39 & 0.43 \\
\hline Most vendors do not have access to the El. Store & 128 & -1.01 & 0.14 \\
\hline El. Trade leads to disruption of existing dis. Channels & 128 & -0.36 & 0.44 \\
\hline Insufficient security of online transactions & 128 & -0.82 & 0.42 \\
\hline Insufficient protection against viruses and hackers & 128 & -0.77 & 0.35 \\
\hline Insufficient eligibility of application manufacturers & 128 & -0.25 & 0.27 \\
\hline $\begin{array}{l}\text { Insufficient qualification of staff for the introduction and main- } \\
\text { tenance of the El. Store system }\end{array}$ & 128 & -0.45 & 0.17 \\
\hline $\begin{array}{l}\text { Lack of knowledge about potential forms of application of El. } \\
\text { Trade }\end{array}$ & 128 & -0.68 & 0.09 \\
\hline $\begin{array}{l}\text { Lack of government standards and legislation on electronic } \\
\text { commerce issues }\end{array}$ & 128 & -0.67 & -0.48 \\
\hline Telecommunication infrastructure is not an adequate & 128 & -0.75 & 0.20 \\
\hline $\begin{array}{l}\text { Lack of national strategy for the development of electronic } \\
\text { commerce }\end{array}$ & 128 & -0.76 & -0.49 \\
\hline $\begin{array}{l}\text { Lack of adequate strategy for the development of electronic } \\
\text { commerce and weak support of the company's top management }\end{array}$ & 128 & -0.81 & 0.12 \\
\hline Lag in the application of new technologies & 128 & -0.80 & 0.06 \\
\hline $\begin{array}{l}\text { Social awareness of customers about electronic commerce is } \\
\text { very small }\end{array}$ & 128 & -0.92 & -0.39 \\
\hline $\begin{array}{l}\text { Cultural and linguistic barriers restrict the use of electronic } \\
\text { commerce }\end{array}$ & 128 & -0.52 & 0.56 \\
\hline Legal regulations & 128 & -0.87 & 0.01 \\
\hline Lack of security & 128 & -0.90 & 0.07 \\
\hline High learning costs & 128 & -0.17 & 0.48 \\
\hline Lack of knowledge & 128 & -0.78 & 0.20 \\
\hline $\begin{array}{l}\text { A small number of companies that developed this aspect of } \\
\text { trade }\end{array}$ & 128 & -0.50 & -0.30 \\
\hline The nature of the products my company produces & 128 & -1.08 & 0.06 \\
\hline
\end{tabular}

As we can see from the Table 1 none of the investigated variables deviated significantly from normal distribution. 
Since all variables according to the indicators used are Skewness I Kurtosis correspond to the requirements of normal distribution, it is justified to apply parametric statistical procedures, including factorial analysis.

Table 3 The following presents the characteristic roots and the percentage of explanations for the variant obtained by implementing the factorial analysis on respondents ' replies to questions on barriers to the introduction of electronic commerce in companies.

Table 3: Characteristic roots and percentage explanation of variance obtained by factorial analysis on respondents ' replies to questions about barriers to the introduction of electronic commerce in the company.

\begin{tabular}{|c|c|c|c|}
\hline & $\begin{array}{c}\text { Characteristic } \\
\text { root }\end{array}$ & \% explained variant & $\begin{array}{c}\text { Cumulative\% of variants } \\
\text { explained }\end{array}$ \\
\hline Factor 1 & 10.93 & $37.7 \%$ & $37.7 \%$ \\
\hline Factor 2 & 2.51 & $8.7 \%$ & $46.3 \%$ \\
\hline Factor 3 & 1.93 & $6.7 \%$ & $53.0 \%$ \\
\hline Factor 4 & 1.85 & $6.4 \%$ & $59.4 \%$ \\
\hline Factor 5 & 1.28 & $4.4 \%$ & $63.8 \%$ \\
\hline Factor 6 & 1.16 & $4.0 \%$ & $67.8 \%$ \\
\hline Factor 7 & 1.10 & $3.8 \%$ & $71.6 \%$ \\
\hline
\end{tabular}

As we see from table 3 Analysis, we extracted seven factors, the first of which explains $37.7 \%$, the second $8.7 \%$, the third $6.7 \%$, the fourth $6.4 \%$, the fifth $4.4 \%$, the sixth $4.0 \%$, and the seventh $3.8 \%$ variant. Table 4 Below brings the factorial structure of the respondent's response to the questions On barriers to the introduction of electronic commerce in companies. 
Table 4: Factorial structure of respondents ' replies to questions on barriers to the introduction of electronic commerce in the company.

\begin{tabular}{|c|c|c|c|c|c|c|c|}
\hline & $\begin{array}{c}\text { Factor } \\
1\end{array}$ & $\begin{array}{c}\text { Factor } \\
2\end{array}$ & $\begin{array}{c}\text { Factor } \\
3\end{array}$ & $\begin{array}{c}\text { Factor } \\
4\end{array}$ & \begin{tabular}{|c|} 
Factor \\
5
\end{tabular} & $\begin{array}{c}\text { Factor } \\
6\end{array}$ & $\begin{array}{c}\text { Factor } \\
7\end{array}$ \\
\hline The costs of introducing electric shops are high & 0.80 & & & & & & \\
\hline Insufficient financial resources & 0.78 & & & & & & \\
\hline Lack of time to introduce El. Store & 0.74 & & & & & & -0.31 \\
\hline $\begin{array}{l}\text { It is necessary to employ additional workers to } \\
\text { deploy and maintain the electric store }\end{array}$ & 0.74 & & & & & & \\
\hline $\begin{array}{l}\text { Non-compliance of investment costs with desired } \\
\text { positive results }\end{array}$ & 0.73 & & & & & & \\
\hline $\begin{array}{l}\text { Information obtained by electric trade is not } \\
\text { useful }\end{array}$ & 0.71 & & -0.30 & -0.38 & & & \\
\hline The market potential of El. Store users is small & 0.70 & & & & & & \\
\hline $\begin{array}{l}\text { Our Sales/marketing requires a high degree of } \\
\text { personal communication }\end{array}$ & 0.69 & & & & & & \\
\hline $\begin{array}{l}\text { El. Trade is not as effective as traditional forms of } \\
\text { marketing }\end{array}$ & 0.69 & & -0.35 & & & & \\
\hline Most vendors do not have access to the El. Store & 0.67 & & & & -0.33 & & \\
\hline $\begin{array}{l}\text { El. Trade leads to disruption of existing dis. } \\
\text { Channels }\end{array}$ & 0.63 & & 0.52 & & & & \\
\hline Insufficient security of online transactions & 0.63 & -0.38 & & & & & \\
\hline Insufficient protection against viruses and hackers & 0.62 & & & & 0.36 & & \\
\hline $\begin{array}{l}\text { Insufficient eligibility of application manufactu- } \\
\text { rers }\end{array}$ & 0.62 & 0.35 & & & & & \\
\hline $\begin{array}{l}\text { Insufficient qualification of staff for the introducti- } \\
\text { on and maintenance of the El. Store system }\end{array}$ & 0.59 & & & & & 0.49 & \\
\hline $\begin{array}{l}\text { Lack of knowledge about potential forms of } \\
\text { application of El. Trade }\end{array}$ & 0.58 & & & 0.44 & & & \\
\hline $\begin{array}{l}\text { Lack of government standards and legislation on } \\
\text { electronic commerce issues }\end{array}$ & 0.58 & -0.56 & & & & & \\
\hline $\begin{array}{l}\text { Telecommunication infrastructure is not an } \\
\text { adequate }\end{array}$ & 0.57 & & & -0.44 & & & \\
\hline $\begin{array}{l}\text { Lack of national strategy for the development of } \\
\text { electronic commerce }\end{array}$ & 0.57 & & & 0.42 & & & \\
\hline $\begin{array}{l}\text { Lack of adequate strategy for the development } \\
\text { of electronic commerce and weak support of the } \\
\text { company's top management }\end{array}$ & 0.55 & -0.49 & & 0.31 & & & \\
\hline Lag in the application of new technologies & 0.52 & 0.31 & 0.45 & & & & \\
\hline $\begin{array}{l}\text { The customer's social awareness of electronic } \\
\text { commerce is very small }\end{array}$ & 0.48 & & & & 0.46 & & \\
\hline $\begin{array}{l}\text { Cultural and linguistic barriers restrict the use of } \\
\text { electronic commerce }\end{array}$ & 0.54 & -0.63 & & & & & \\
\hline Legal regulations & 0.48 & 0.59 & & & & & \\
\hline Lack of security & 0.40 & 0.51 & & & & & \\
\hline High learning costs & 0.44 & & 0.31 & -0.57 & & & \\
\hline Lack of knowledge & 0.39 & & -0.45 & 0.46 & & & 0.34 \\
\hline $\begin{array}{l}\text { A small number of companies that developed this } \\
\text { aspect of trade }\end{array}$ & 0.59 & & & & & 0.61 & \\
\hline $\begin{array}{l}\text { The nature of the products which my company } \\
\text { produces }\end{array}$ & 0.49 & & & & & & -0.52 \\
\hline
\end{tabular}

If we look at Table 4 See how Factor 1 Potential barriers to the introduction of electronic commerce in the company while the remaining factors are in a non-systematic way linked to some of the possible barriers. 
When we talk about the content interpretation of the results Factor 1 We can call $A$ general factor of barriers to the introduction of electronic commerce in the company, while the remaining factors are uninterpretable, or we can look at them as if their characteristic roots are not significant (greater than 1).

\subsubsection{Benefits from the application of electronic commerce in companies}

In order to investigate the benefits estimates of the application of electronic commerce in companies calculated the arithmetic mean and standard deviation of the response for each potential benefit. Each potential benefit was evaluated at five degrees of the Likert's scale: Very low, low, moderate, high and very high. The results are given in Table 5.

Table 5: Arithmetic mean and standard deviation of the respondent's response to questions about the potential benefit of introducing an electronic trade in the company.

\begin{tabular}{|l|c|c|c|}
\hline & $\begin{array}{c}\text { Number of } \\
\text { respondents }\end{array}$ & $\begin{array}{c}\text { Arithmetic } \\
\text { mean }\end{array}$ & $\begin{array}{c}\text { Standard } \\
\text { deviation }\end{array}$ \\
\hline Increasing market share & 128 & 3.09 & 1.19 \\
\hline Increase profit & 128 & 3.10 & 1.16 \\
\hline Increase production & 128 & 2.70 & 1.15 \\
\hline Increase in return on investment & 128 & 2.86 & 1.20 \\
\hline Improving the quality of customer service & 128 & 3.48 & 1.24 \\
\hline Easier access to end users & 128 & 3.52 & 1.26 \\
\hline $\begin{array}{l}\text { Better communication and improvement } \\
\text { of information exchange with end-users }\end{array}$ & 128 & 3.50 & 1.27 \\
\hline Increase customer loyalty & 128 & 3.24 & 1.27 \\
\hline Increase efficiency in working with vendors & 128 & 3.28 & 1.25 \\
\hline Saving Time & 128 & 3.73 & 1.27 \\
\hline $\begin{array}{l}\text { Improvement of the company's recognition and } \\
\text { image }\end{array}$ & 128 & 3.60 & 1.29 \\
\hline Improving the efficiency of business processes & 128 & 3.47 & 1.22 \\
\hline Access to new markets & 128 & 3.53 & 1.27 \\
\hline
\end{tabular}

In Table 5 we see that respondents considered that application of electronic commerce provides easier access to end users $(\mathrm{M}=3,52 ; \mathrm{SD}=1.26)$, better communication and improvement of information exchange with end-users $(\mathrm{M}=3.50 ; \mathrm{SD}=1.27)$, saving time $(\mathrm{M}=3,73 ; \mathrm{SD}=1.27)$, improvement of the company's recognition and image $(\mathrm{M}=3.60 ; \mathrm{SD}=1.29)$ and access to new markets $(\mathrm{M}=3.53 ; \mathrm{SD}=1.27)$. For all other claims, they consider them to benefit from the introduction of electronic commerce: increasing market share $(\mathrm{M}=3.09$; $\mathrm{SD}=1.19)$, profit increase $(\mathrm{M}=$ 3.10; $\mathrm{SD}=1.16)$, production increase $(\mathrm{M}=2,70 ; \mathrm{SD}=1.15)$, increase in return on investment $(\mathrm{ROI})(\mathrm{M}=2.86 ; \mathrm{SD}=1.20)$, improvement of customer service quality $(\mathrm{M}=3.48 ; \mathrm{SD}=1.24)$, increase in customer loyalty $(\mathrm{M}=3.24 ; \mathrm{SD}=1.27)$, increase 
in efficiency in working with suppliers $(\mathrm{M}=3,28 ; \mathrm{SD}=1.25)$ and improving the efficiency of business processes $(\mathrm{M}=3,47$; $\mathrm{SD}=1.22)$.

Table 6 below provides the results of checking the normality of distribution of respondents ' replies to questions about the potential benefit of introducing an electronic trade in the company. Indicators that were used are kurtosis and skewness.

Table 6: Check the normality of the distribution of the responder's response to questions about the potential benefit of introducing an electronic trade in the company.

\begin{tabular}{|l|c|c|c|}
\hline & $\begin{array}{c}\text { Number of } \\
\text { respondents }\end{array}$ & Kurtosis & Skewness \\
\hline Increasing market share & 128 & -0.648 & -0.356 \\
\hline Increase profit & 128 & -0.414 & -0.388 \\
\hline Increase production & 128 & -0.532 & 0.018 \\
\hline Increase in return on investment & 128 & -0.688 & 0.054 \\
\hline Improving the quality of customer service & 128 & -0.386 & -0.619 \\
\hline Easier access to end users & 128 & -0.289 & -0.766 \\
\hline $\begin{array}{l}\text { Better communication and improvement } \\
\text { of information exchange with end-users }\end{array}$ & 128 & -0.327 & -0.778 \\
\hline Increase customer loyalty & 128 & -0.730 & -0.444 \\
\hline Increase efficiency in working with vendors & 128 & -0.673 & -0.452 \\
\hline Saving Time & 128 & -0.096 & -0.866 \\
\hline $\begin{array}{l}\text { Improvement of the company's recognition and } \\
\text { image }\end{array}$ & 128 & -0.468 & -0.682 \\
\hline Improving the efficiency of business processes & 128 & -0.321 & -0.596 \\
\hline Access to new markets & 128 & -0.457 & -0.614 \\
\hline
\end{tabular}

In Table 6 we see that none of the investigated variables deviated significantly from normal distribution. Since all variables according to the indicators skewness and kurtosis correspond to the requirements of normal distribution, it is justified to apply parametric statistical procedures, including factorial analysis.

Table 7 shows characteristic roots and percentage of explanations of the variant obtained by implementing the factorial analysis on respondents ' replies to questions about the potential benefit of introducing an electronic trade in the company.

Table 7: Characteristic roots and percentage of explanations of variance obtained by factorial analysis on respondents ' replies to questions about the potential benefit of introducing electronic commerce in the company.

\begin{tabular}{|c|c|c|c|}
\hline & $\begin{array}{c}\text { Characteristic } \\
\text { root }\end{array}$ & \% explained variant & $\begin{array}{c}\text { Cumulative\% of variants } \\
\text { explained }\end{array}$ \\
\hline Factor 1 & 9.31 & $71.6 \%$ & $71.6 \%$ \\
\hline Factor 2 & 1.14 & $8.8 \%$ & $80.4 \%$ \\
\hline
\end{tabular}

As we see from table 7 analysis, we extracted two factors, the first explains $71.6 \%$ and the other $8.8 \%$, respectively of total $80.4 \%$ of variants. 
Table 8 below provides the factorial structure of the respondents ' response to questions about the potential benefit of introducing an electronic trade in the company.

Table 8: Factorial structure of respondents ' response to questions about the potential benefit of introducing an electronic trade in the company.

\begin{tabular}{|l|c|c|}
\hline & Factor 1 & Factor 2 \\
\hline Increasing market share & 0.89 & \\
\hline Increase profit & 0.89 & \\
\hline Increase production & 0.89 & \\
\hline Increase in return on investment & 0.88 & \\
\hline Improving the quality of customer service & 0.88 & \\
\hline Easier access to end users & 0.88 & \\
\hline $\begin{array}{l}\text { Better communication and improvement of information } \\
\text { exchange with end-users }\end{array}$ & 0.86 & \\
\hline Increase customer loyalty & 0.86 & 0.34 \\
\hline Increase efficiency in working with vendors & 0.85 & 0.38 \\
\hline Saving Time & 0.83 & \\
\hline Improvement of the company's recognition and image & 0.81 & \\
\hline Improving the efficiency of business processes & 0.78 & 0.51 \\
\hline Access to new markets & 0.68 & 0.54 \\
\hline
\end{tabular}

If we look at the table 8 we see how Factor 1 is associated with all the aforementioned potential benefits of introducing electronic commerce in the company, Factor 2 is related to the four potential benefits of introducing an electronic trade in the company in the same direction as Factor 1.

When we talk about the content interpretation of the results, we can name Factor 1 as the General factor of the usability of introducing electronic commerce into the company, while the Factor 2 is uninterpretable, or we can look at it as if its characteristic root is not significant (greater than 1).

\section{CONCLUSION}

In this work, the current state and representation of electronic commerce in companies in Bosnia and Herzegovina is analyzed. In this context, it looked at the state of the infrastructure for the possibilities of electronic commerce. By conducting the research, the degree of engagement of electronic technology in the companies was observed, the current legal regulations for the development of electronic commerce were investigated.

Despite the increase in the flow of transactions and information exchange in electronic form, however, the development of electronic commerce in our country and the region is significantly lagging behind the other regions of Europe and the developed countries of the world. The results of the survey show that there is a number of companies in Bosnia and Herzegovina which work on the development of electronic commerce, but also the trade has not reached a significant level, so that the statistics 
of Bosnia and Herzegovina do not allocate electronic commerce as a special segment of trade, unlike some countries in the region such as Srbija and Croatia, where the participation of electronic commerce in the country's comprehensive trade.

Of course, the electronics store has its future in Bosnia and Herzegovina, because in the world, this kind of business has been widespread for long. To improve the development of electronic commerce it is necessary to include all relevant factors, primarily the state through the adaptation of the laws and regulations in general, to do the strategy of the development of electronic commerce and to implement education both citizens and companies, public institutions and other organizations. In addition, Bosnia and Herzegovina must work on harmonization of regulations and standards with international standards, since the electronic trade of interventions is an international scale.

So further development of electronic commerce is certain, but it is necessary to include the most important trends and seek innovative solutions, which can improve this development both in quantitative and qualitative sense.

\section{REFERENCES}

1. Baggott, C., 2007. Email Marketing by the Num8ers, Hoboken, John Wiley \& Sons, Inc., New Jersey.

2. Carey, P., 2001. The Internet and E-Commerce: A hawksmere Report. London.

3. Dave Chafefey, D., 2003. Total E-mail Marketing, Marketing Insight Ltd., Oxford.

4. Domazet, A., etc., 2010. Development of trade and domestic market in the Federation of Bosnia and Herzegovina, Institute of Economics, Sarajevo; Institute of Economics, Zagreb.

5. The National Assembly of Republic of Srpska, 2008. "Official Journal of Republic of Srpska", No. 59/08.

6. The National Assembly of Republic of Srpska, 2008. "Official Journal of Republic of Srpska", No. 110/08.

7. The National Assembly of Republic of Srpska, 2009. "Official Journal of Republic of Srpska”, No. 59/09.

8. Agency for Information Society of the entity of Republic of Srpska, 2012. Legal acts allowing the use of e-services, [online]. Available at: http://www. aidrs.org/legislativa/zakonski_akti_koji_omogucuju_primjenu_e-Service [Access: 03.01.2012] 
9. Yellow Pages International \& Yellow Pages Bosnia, Business directory Yellow page, [online]. Available at: Http://www.yellowpages-ba.com/glavna. htm, [Access: 15.01.2012]

10. Editus Sarajevo, Ko What works in BiH-Bosnia and Herzegovina Business Directory, [online]. Available at: Http://www.kostaradi.com [Access: 15.01.2012]

11. Mapabih, economic operator database, [online]. Available at: http://www. mapabih.com/index2.php?, [Access: 03.01.2012]

\section{ZASTUPLJENOST I RAZVIJENOST ELEKTRONSKE TRGOVINE U KOMPANIJAMA U BOSNI I HERCEGOVINI}

\section{SAŽETAK}

Razvoj informacionih tehnologija u svijetu i njihov uticaj na sve aspekte ljudskog života i rada uveliko se odražava i na prostore Bosne i Hercegovine. Ovo je vrijeme kada većina kompanija prelazi na elektronski način poslovanja. Danas je bez Interneta i elektronskog poslovanja praktično nezamislivo realizovati zacrtane poslovne ciljeve $i$ što efikasnije provoditi poslovne procese.

U svrhu spoznaje koliko je elektronska trgovina zastupljena u poslovnom svijetu $u$ Bosni i Hercegovini, da Ii je prihvaćena od strane kompanija, ustanova $i$ drugih orgnizacija, da Ii je koriste i šta misle o elektronskoj trgovini, provedeno je i ovo istraživanje.

Cilj rada je da istraži zastupljenost i razvijenost elektronske trgovine u kompanijama u Bosni i Hercegovini, kao i da ispita koji su to preduvjeti koji se moraju ispuniti za uspješan razvoj elektronske trgovine.

Istraživanje se baziralo na provođenju ankete sa cca. 250 kompanija u Bosni i Hercegovini. Anketiranje je provedeno elektronskim putem. Ograničenja pri istraživanju sastoje se u tome što se istraživanje provodi u zemlji u razvoju gdje je primjena informacionih tehnologija daleko na nižem nivou u odnosu na razvijene zemlje.

Ključne riječi: Elektronska trgovina, kompanije, Bosna i Hercegovina, razvoj elektronske trgovine.

JEL: $M 37$ 